\title{
IRISH
}

\section{REGIMENTS IN THE}

GREAT WAR

DISCIPLINE AND MORALE

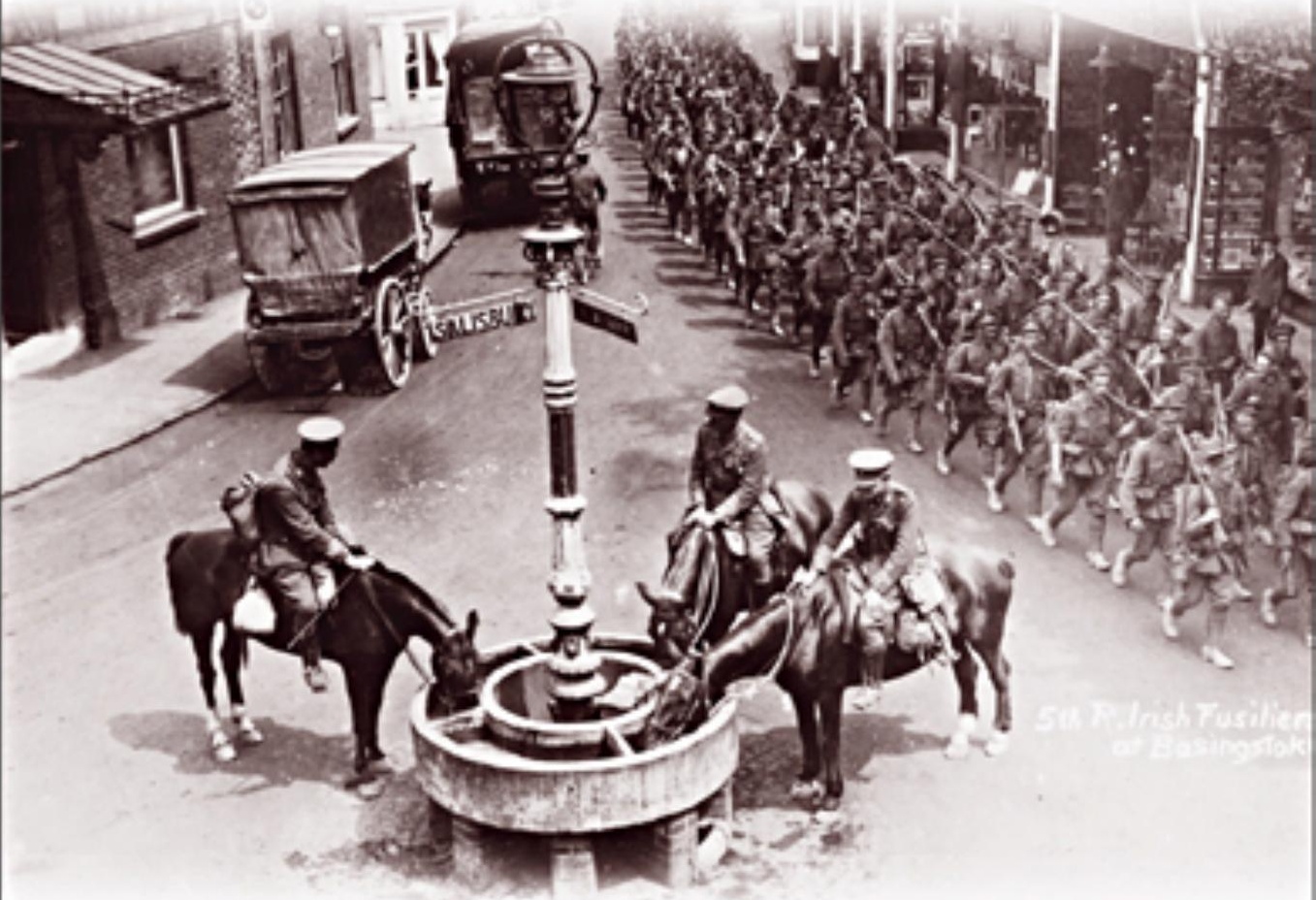

Timothy Bowman 


\section{The Irish regiments in the Great War}

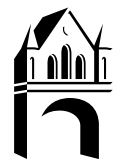

MANCHESTER

UNIVERSITY PRESS 
Timothy Bowman - 9781847791290 Downloaded from manchesterhive.com at $04 / 26 / 2023$ 01:49:25PM 


\title{
The Irish regiments in the Great War
} Discipline and morale

\author{
TIMOTHY BOWMAN
}

\author{
Manchester University Press \\ Manchester and New York
}

distributed exclusively in the USA by Palgrave 
Copyright (C) Timothy Bowman 2003

The right of Timothy Bowman to be identified as the author of this work has been asserted by him in accordance with the Copyright, Designs and Patents Act 1988.

Published by Manchester University Press

Oxford Road, Manchester M13 9NR, UK

and Room 400, 175 Fifth Avenue, New York, NY 10010, USA

www.manchesteruniversitypress.co.uk

Distributed exclusively in the USA by

Palgrave, 175 Fifth Avenue, New York,

NY 10010, USA

Distributed exclusively in Canada by

UBC Press, University of British Columbia, 2029 West Mall,

Vancouver, BC, Canada V6T 1Z2

British Library Cataloguing-in-Publication Data

A catalogue record for this book is available from the British Library

Library of Congress Cataloging-in-Publication Data applied for

ISBN 0719062845 hardback

First published 2003

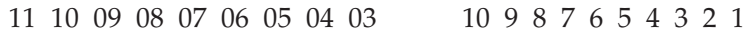

Typeset in Palatino

by Action Publishing Technology Ltd, Gloucester

Printed in Great Britain

by Bookcraft (Bath) Ltd, Midsomer Norton 